\title{
MENGEMBANGANKAN BAHAN AJAR MATAKULIAH TRIGONOMETRI YANG INTEGRASI-INTERKONEKSI BERBASIS SOFTWARE MAPLE PADA JURUSAN PENDIDIKAN MATEMATIKA IAIN MATARAM
}

\author{
Kristayulita $^{1}$, Nurhilaliati ${ }^{2}$ \\ ${ }^{1,2}$ Jurusan Tadris Matematika, Universitas Islam Negeri Mataram \\ Jalan Pendidikan No 35, Dasan Agung Baru, Selaparang, Mataram, Indonesia \\ e-mail: ${ }^{1}$ kristayulita@uinmataram.ac.id;
}

\begin{abstract}
Abstrak
Penelitian ini bertujuan untuk mengembangkan bahan ajar Matakuliah Trigonometri yang integrasiinterkoneksi berbasis software Maple pada mahasiswa Tadris Matematika. Penelitian pengembangan yang menggunakan model Hannafin dan Peck. Hasil penelitian menunjukkan bahwa bahan ajar layak digunakan. Berdasarkan persepsi pakar dan mahasiswa terkait dengan aspek isi/materi dan aspek penyajian dinilai baik dan memuaskan. Penggunaan Maple masih pada tingkat $65 \%$ - $80 \%$ dalam materi bahan ajar trigonometri. Hal ini disebabkan oleh ada beberapa materi trigonomteri yang tidak bisa digunakan dengan menggunakan Maple seperti dalam membuktikan rumus identitas dari trigonometri. Maple digunakan dalam menyelesaiakan masalah. Ketuntasan Belajar mahasiswa pada mata kuliah Trigonometri sebesar $72 \%$ lebih besar dari ketuntasan yang ditentukan sebesar $70 \%$. Integrasi dan interkoneksi nilai Islam dalam materi trigonometri belum terlalu nampak.
\end{abstract}

Kata Kunci: integrasi-interkoneksi, pengembangan bahan ajar, software maple, trigonometri

\section{DEVELOPING OF TRIGONOMETRY MATERIALS WITH INTEGRATION-INTERCONNECTION BASED ON SOFTWARE MAPLE ON MATHEMATICAL EDUCATION DEPARTMENT IAIN MATARAM}

\begin{abstract}
This study aims to develop Maple Trigonometry-integrated Trigonometry Course teaching materials for students on Mathematics Department. The Development research using Hannafin and Peck models. The results show that teaching materials are appropriate to use. Based on the perceptions of experts and students related to the material aspects and presentation aspects are considered good and satisfying. The use of Maple is still at the level of $65 \%-80 \%$ in trigonometric teaching material. This is caused by some trigonometry material which cannot be used using Maple as in proving the identity formula of trigonometry. Maple is a tool for solving the problems. Learning submission for students in Trigonometry courses is $72 \%$ greater than the completeness determined by $70 \%$. Integration and interconnection of Islamic values in trigonometric material is not yet occurring.
\end{abstract}

Keywords: integration-interconnection, development of teaching materials, software maple, trigonometry

\section{Pendahuluan}

Jurusan pendidikan matematika mempunyai keunikan tersendiri dalam hal kurikulumnya sekaligus yang membedakan dengan jurusan pendidikan matematika di kampus yang lain. Salah satu keunikannya adalah memiliki matakuliah trigonometri. Karena keunikannya ini membuat buku paket matakuliah trigonometri yang menjadi rujukan/refernsi jarang ditemukan di perpustakaan maupun di toko-toko buku. Hal ini disebabkan materi trigonometri termuat dalam sub materi matakuliah-matakuliah yang lain seperti Kalkulus 1, Kalkulus 2, Persamaan Diferensial dan sebagainnya. 
Untuk mengatasi kekurangan referensi/ sumber bacaan matakuliah trigonometri digunakan media yang memungkinkan pengadaannya bagi mahasiswa. Penggunaan sumber belajar/media belajar merupakan suatu bentuk strategis yang memungkinkan proses pembelajaran menjadi lebih efektif dan efesien. Melalui pemanfaatan sumber/media pembelajaran, mahasiswa dapat dengan fleksibel menentukan waktu belajar kapan saja, dimana saja, menyesuaikan dengan kecepatan gaya belajarnya . Sumber/media belajar yang digunakan adalah media cetak atau yang biasa dikenal sebagai modul. Sebagi media cetak, modul mempunyai karakteristik yang bersifat khas diantaranya adalah: (1) self instructional, yaitu mampu membelajarkan diri sendiri, tidak tergantung pada pihak lain; (2) self contained, yaitu seluruh materi pembelajaran dari satu pokok bahasan atau sub pokok bahasan yang dipelajari terdapat di dalam modul secara utuh; (3) stand alone, yaitu modul yang dikambangkan tidak tergantung pada modul lain; (4) adaptic, yaitu harus memiliki daya adaptif yang tinggi terhadap perkembangan ilmu dan teknologi dan (5) user friendly, yaitu memenuhi kaidah bersahabat dengan pemakainya serta (6) consistent, yaitu layout dan format yang dibuat konsisten dan mudah dimengerti pengguna.

Beberapa langkah yang harus dilakukan dalam proses pengembangan bahan ajar secara bertahap, meliputi: analisis instruksional, desain, pengembangan, uji coba, implementasi, dan evaluasi . Dalam kaitannya dengan evaluasi bahan aja, perlu suatu perangkat pengembangan bahan ajar yang menjadi acuan bagi evaluator untuk dilakukan evaluasi.

Evaluasi ini dapat berbentuk kajian materi bahan ajar yang mengkaji relevansi materi bahan ajar dengan kebutuhan mahasiswa dan kemuthirannya materi bahan ajar yang diekmbangkan berikut cara penyajiannya. Perangkat pengembangan bahan ajar yang akan dikaji meliputi: Deskripsi matakuliah, Peta Kompetensi Mata Kuliah Berdasarkan Hasil Analisis Instruksional Dan Garis-Garis Besar Program Pengajaran serta buku materi yang sesuai dengan matakuliah trigonometri. Melalui kajian bahan ajar dari suatu matakuliah yang menyeluruh dapat diketahui rancangan matakuliah, kualitas materi bahan ajar, kualitas interaksi mahasiswa dengan bahan ajar dan media serta kualitas proses pembelajaran. Kesemua hal tersebut merupakan indikator yang paling penting dari kualitas matakuliah. Apabila jurusan pendidikan matematika IAIN Mataran telah memiliki matakuliah dengan bahan ajar yang berkualitas, amak keadaan ini akan meningkatkan kualitas proses pembelajaran di jurusan pendidikan matematika sebagai salah satu jurusan yang ada di fakultas Ilmu Tarbiyah dan Keguruan IAIN Mataram serta kekurangan referensi/sumber bacaan teratasi.

Jurusan pendidikan matematika S1 diselenggarakan dalam rangka meningkatkan kualitas mahasiswa pendidikan matematika Fakultas Ilmu Tarbiyah dan Keguruan IAIN Matematika yang berminat di bidang keguruan atau tenaga pendidik. diharapkan lulusan dapat menjadi tenaga pendidik yang mampu menerapkan ilmu matematika (trigonometri) kepada siswa-siswi di sekolah atau madrasah.

Dalam struktur kurikulum S1 Jurusan Pendidikan Matematika, salah satu matakuliah yang ditawarkan adalah Trigonometri. Trigonometri merupakan matakuliah dasar wajib memiliki bobot 2 SKS yang harus ditempuh oleh mahasiswa. Selain itu, materi Trigonometri merupakan salah satu konsep matematika yang sangat penting dalam menjelaskan persoalan manusia. Salah satu tentang penetapan tanggal 1 Ramadhan dan tanggal 1 Syawal setiap tahun Hijriah. Konsep trigonometri memiliki peranan yang sangat besar dalam perhitungan (hisab). Hal ini, tergambar adanya integrasi-interkoneksi antara konsep trigonometri dan ilmu agama. Integrasi-interkoneksi terjadi pada level materi menghubungkan materi trigonometri dangan ilmu agama dalam pengajaran matakuliah. Tujuan dari Integrasi-Interkoneksi adalah untuk memahami kehidupan manusia yang kompleks secara terpadu dan menyeluruh. Dengan harapan IntegrasiInterkoneksi adalah (1) terwujudnya manusia yang mulya (Q.S. Al-Mujadilah:11) dan (2) manusia yang mulia (berderajat tinggi) (Q.S. AlMujadilah: 11). Adapun berderajat tinggi di sini adalah manusia yang beriman, berilmu, dan beramal shalih.

Maple adalah suatu program aplikasi komputer untuk matematika yang diproduksi oleh Waterloo Maple Inc., Ontario Canada. Program ini pada awalnya dikembangkan oleh civitas University of Waterloo, Canada tahun 1988. Maple merupakan suatu sistem komputasi simbolik (Symbolic Computation System) interaksi yang sangat kuat. Program ini telah banyak digunakan oleh kalangan pelajar, pendidik, matematikawan, statistikawan, ilmuwan dan insinyur untuk mengerjakan komputasi numerik dan simbolik (Gravan, 2002). 
Selain sarana untuk melakukan kompuatsi, Maple dapat dimanfaatkan di berbagai bidang termasuk bidang pendidikan. Pemanfaatan software Maple banyak dilakukan dalam hal menentukan suatu solusi dari berbagai macam persoalan matematika yang ditanyakan. Sehingga sangat memungkinkan untuk digunakan sebagai salah satu alternatif dalam pemilihan media pembelajaran.

\section{Metode Penelitian}

Penelitian ini merupakan penelitian pengembangan dengan model Hannafin dan Peck. Model pengembangan Hannafin dan Peck merupakan model yang sederhana, hanya terdiri dari tiga fase saja yaitu fase analisis keperluan, fase desain dan fase pengembangan atau implementasi.

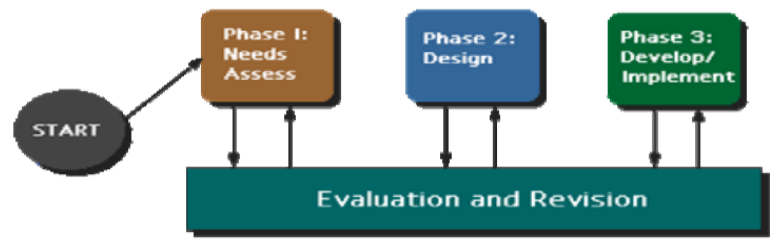

Gambar 1. Model Hannafin dan Peck

Model pengembangan di atas peneliti kembangkan sesuai dengan kebutuhan dalam penelitian ini. Hasil pengembangannya adalah sebagai berikut:

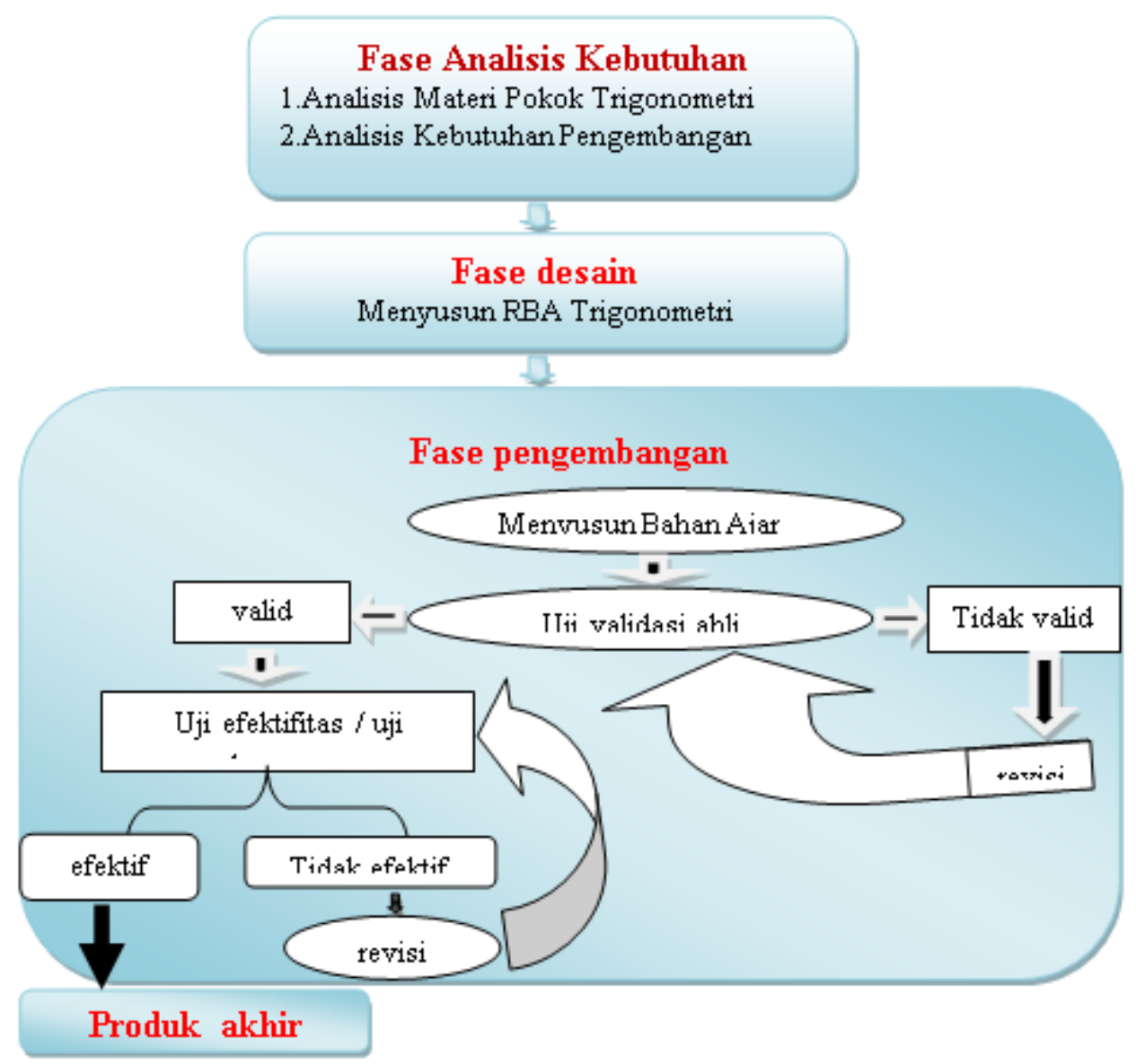

Gambar 2. Alur Fase Pengembangan

\section{Hasil dan Pembahasan}

\subsection{Responden yang digunakan}

Responden pada penelitian ini adalah beberapa mahasiswa semester II yang mewakili dari seluruh mahasiswa semester II Jurusan Pendidikan Matematika Fakultas Ilmu Tarbiyah dan Keguruan (FITK) Institut Agama Islam Negeri (IAIN) Mataram. Jumlah responden yang dipakai sebanyak 26 orang merupakan perwakilan dari mahasiswa semester II yang diambil dari kelas A. Responden ini digunakan untuk mengambil data persepsi mahasiswa terhadap isi/materi dari bahan ajar dan prestasi belajar.

Khusus pakar/nara sumber berasal dari salah seorang dosen di Jurusan Pendidikan Matematika yang ahli di matematika. Pakar akan melakukan telaah secara mendalam materi dengan acuan instrumen yang sudah ada dan berasal dari bahan materi kegiatan reviuw pakar bahan ajar.

\subsection{Kompetensi bahan ajar}


Kompetensi bahan ajar Trigonometri berdasarkan Tujuan Mata kuliah, dan Tujuan Umum pada kondisi awal dan pendapat/masukan dari pakar/referensi yang dapat dilihat pada tabel 1.

Tabel 1. Kompetensi bahan ajar trigonometri

\begin{tabular}{|r|l|l|}
\hline No & \multicolumn{1}{|c|}{ Kondisi Awal } & \multicolumn{1}{c|}{ Masukan } \\
\hline 1 & $\begin{array}{l}\text { Deskripsi Matakuliah: } \\
\text { Membahas tentang }\end{array}$ & $\begin{array}{l}\text { Secara umum sudah mencakup materi yang akan dibahas, namun } \\
\text { demikian perlu penambahan dan koreksi beberapa uraian sub pokok } \\
\text { bahasan, sehingga lebih fokus dan tuntas, dengan menampilkan } \\
\text { penyelesaian contoh-contoh soal yang lebih banyak lagi. }\end{array}$ \\
\hline 2 & $\begin{array}{l}\text { Garis Besar Program Pengajaran: } \\
\text { Dapat dilihat pada Tabel 4.3. }\end{array}$ & $\begin{array}{l}\text { Kompetensi umum dalam Garis Besar Program Pengajaran harus } \\
\text { disesuaikan Peta Kompetensi dan Tinjauan mata kuliah dalam } \\
\text { bebrapa Buku yang terkait dengan materi pokok trigonometri. } \\
\text { Bahan ajar non cetak harus disesuaikan dengan jenis/bentuk } \\
\text { bantuan belajar yant tersedia di perpustakan IAIN Mataram saat ini. } \\
\text { Materi/suatu konsep dari seluruh pokok dan sub poko bahasan } \\
\text { harus jelas secara tuntas dan perlu diberikan contoh kasus sebagai } \\
\text { ilustrasi materi. Uraian pokok bahasan dan sub bahasan perlu } \\
\text { ditambahkan konsep yang lebih lengkap dan informasi kekinian } \\
\text { yang sesuai dengan perkembangan terbaru. }\end{array}$ \\
& $\begin{array}{l}\text { Analisis Instruksional dalam bentuk } \\
\text { peta kompetensi dapat dilihat pada } \\
\text { Gambar 4.1. }\end{array}$ & $\begin{array}{l}\text { Perluan lebih detail tentang uraian sub pokok bahasan dan } \\
\text { disesuaikan dengan masukan materi yang harus ditambahkan dan } \\
\text { diperbaiki. Kompetensi umum harus sesuai dengan Garis Besar } \\
\text { Program Pengajaran dan tinjauan mata kuliah. }\end{array}$ \\
\hline
\end{tabular}

Tabel 2. Tujuan Matakuliah dan Tujuan Umum dari matakuliah trigonometri

\begin{tabular}{|c|c|c|}
\hline No & Tujuan Mata Kuliah & Tujuan Umum \\
\hline 1 & $\begin{array}{l}\text { Menguasai perbandingan trigonometri, } \\
\text { rumus trigonomteri, persamaan } \\
\text { trigonometri, fungsi trigonometri, limit } \\
\text { fungsi trigonometri, dan turunan fungsi } \\
\text { trigonometri, membuktikan rumus-rumus } \\
\text { trigonometri serta mengaplikasi fungsi } \\
\text { trigonometri dan dapat dijadikan materi } \\
\text { penunjang untuk mata kuliah lainnya. }\end{array}$ & $\begin{array}{l}\text { 1. Mahasiswa mampu menentukan perbandingan pada suatu } \\
\text { segitiga siku-siku. } \\
\text { 2. Mahasiswa mampu menjelaskan konsep Phytagoras, } \\
\text { aturan sinus, dan aturan kosinus serta dapat } \\
\text { menyelesaikan soal yang berkaitan. } \\
\text { 3. Mahasiswa mampu menentukan himpunan penyelesaian } \\
\text { dari persamaan dan pertidaksamaan trigonometri } \\
\text { 4. Mahasiswa mampu menjelaskan konsep rumus-rumus } \\
\text { trigonometri dan dapat menyelesaikan soal yang } \\
\text { berkaitan } \\
\text { 5. Mahasiswa mampu menjelaskan konsep fungsi } \\
\text { trigonometri. } \\
\text { 6. Mahasiswa mampu menggambar fungsi trigonometri } \\
\text { serta dapat menyelesaikan soal yang berkaitan } \\
\text { Mahasiswa mampu menjelaskan konsep limit fungsi } \\
\text { trigonometri serta dapat menyelesaikan soal yang } \\
\text { berkaitan } \\
\text { Mahasiswa mampu menjelaskan konsep turunan fungsi } \\
\text { trigonometri dan dapat menyelesaiakan persoalan yang } \\
\text { berkaitan }\end{array}$ \\
\hline
\end{tabular}

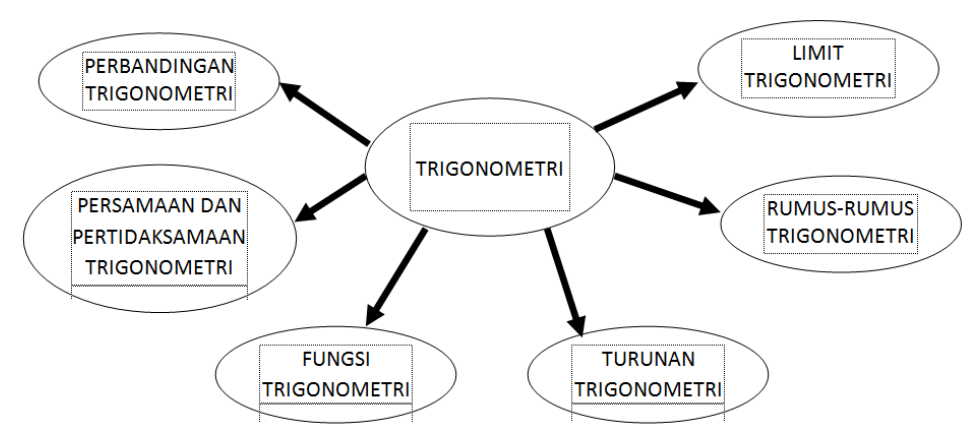

Gambar 3. Peta Konsep Trigonometri 


\subsection{Aspek Isi/ Materi}

Peninjauan aspek isi/ materi mata kuliah Trigonometri terdiri dari:

a. Keakuratan materi, dengan tolak ukur penilaian yang ditanyakan kepada mahasiswa adalah mengenai materi bahan ajar disampaikan tanpa menimbulkan banyak tafsir dan diberikan secara konsisten dan runut.

b. Alur dan kelengkapan materi, dengan penilaian adalah materi bahan ajar disampaikan secara lengkap dan relevan dengan topik.

c. Kumuktahiran dan pengayaan materi, dengan tolak ukur penilaian meliputi: (1) penerapan materi menggunakan konteks yang bervariasi dan berkaitan dengan informasi terbaru, dan (2) dalam uraian diperkenalkan berbagai contoh dan non contoh yang dapat lebih memperjelas materi.

d. Ketepatan terhadap sasaran pembaca, dengan penilaian isi materi sesuai dengan kompetensi yang dibutuhkan untuk mahasiswa S1

e. Tingkat kesulitan naskah bacaan, dengan tolak ukur penilaian materi yang disampaikan mudah dipahami dengan tingkat kesulitan yang sedang.

Berdasarkan analisis data terlengkap bahwa seluruh mahasiswa (100\%) menjawab atau mengakui adanya perspsi positif terhadap komponen-komponen berikut: (1) keakuratan materi, (2) alur dan kelengkapan materi, (3) kemuktahiran dan pengayaan materi untuk tolak ukur pemaparan materi menggunakan konteks yang bervariasi dan berkaitan dengan informasi terbaru, dan (4) ketepatan terhadap sasaran pembaca.

Untuk komponen-komponen lainnya dapat dijelaskan sebagai berikut:

a. Untuk tingkat kesulitan naskah bacaan, sebagian besar mahasiswa (76,92\%) memberikan persepsi bahwa materi yang disampaikan mudah dipahami dengan tingkat kesulitan yang sedang. Data ini memberi petunjuk bahwa masih ada sejumlah mahasiswa $(23,08 \%)$ yang mempunyai persepsi bahwa mata kuliah Trigonometri tidak mudah dipahami. Hal ini terungkap dari beberapa argumentasi yang mereka sampaikan antara lain; banyak materi yang sulit dipahami, belum memahami secara menyeluruh, sulit memahami materi yang baru, materi sulit dipahami karena banyak simbol-simbol matematika tidak diketahui.

b. Untuk komponen kemutahiran dan pengayaan materi, persepsi mahasiswa sebagian besar $(73,08 \%)$ memberi persepsi bahwa dalam uraian diperkenalkan berbagai contoh yang dapat lebih menjelaskan materi. Artinya sebagian mahasiswa sisanya, yakni 26,92\% memberi persepsi bahwa mata kuliah Trigonometri masih belum cukup uraian yang dapat lebih menjelaskan materi bahasan. Hal ini terungkap dari beberapa penegasan mahasiswa yaitu ada contoh yang masih belum sesuai dengan pokok bahasan, tidak mengerti contoh yang diberikan karena materinya tidak dipahami, contoh yang disajikan belum bisa menjelaskan maksud materi bahasan.

Secara lengkap persepsi mahasiswa terhadap aspek isi/materi mata kuliah Trigonometri dapat dilihat pada Tabel 3. Analisis data memberikan gambaran bahwa dari beberapa tolok ukur komponen isi/materi matekuliah Trigonometri, persepsi mahasiswa yang terendah secara berturut-turut adalah pada tolok ukur: (1) tingkat kesulitan naskah bacaan, dengan mahasiswa menjawab sulit dipahami sebanyak 23,08\%; dan (2) kemutahiran dan pengayaan materi untuk parameter contoh uraian yang dapat memperjelas materi, dengan persentase mahasiswa yang menjawab tidak sebesar $26,92 \%$.

Tabel 3. Hasil Persepsi Mahasiswa Terhadap Aspek Isi/Materi Matakuliah Trigonometri

\begin{tabular}{|c|l|c|c|}
\hline No & \multicolumn{1}{|c|}{ Kriteria } & \multicolumn{1}{c|}{ Jawaban (\%) } \\
\cline { 2 - 3 } & \multicolumn{1}{|c|}{ Ya } & Tidak \\
\hline 1 & $\begin{array}{l}\text { Keakuratan materi. } \\
\text { Pertanyaan: Apakah bahan ajar disampaikan tanpa menimbulkan banyak tafsir dan } \\
\text { diberikan secara konsisten dan runut }\end{array}$ & 93,31 & 7,69 \\
\hline 2 & $\begin{array}{l}\text { Alur dan kelengkapan materi. } \\
\text { Pertanyaan: Apakah materi bahan ajar disampaikan secara lengkap dan relevan } \\
\text { dengan topik. }\end{array}$ & 88,46 & 11,54 \\
\hline $3 a$ & $\begin{array}{l}\text { Kumuktahiran dan pengayaan materi. } \\
\text { Pertanyaan: Apakah penerapan materi menggunakan konteks yang bervariasi dan } \\
\text { berkaitan dengan informasi terbaru }\end{array}$ & 73,08 & 26,92 \\
\hline
\end{tabular}




\begin{tabular}{|c|l|l|l|}
\hline $3 b$ & $\begin{array}{l}\text { Kumuktahiran dan pengayaan materi. } \\
\text { Pertanyaan: Apakah dalam uraian diperkenalkan berbagai contoh yang dapat lebih } \\
\text { memperjelas materi }\end{array}$ & 92,31 & 7,69 \\
\hline 4 & $\begin{array}{l}\text { Ketepatan terhadap sasaran pembaca, } \\
\text { Pertanyaan: Apakah dengan penilaian isi materi sesuai dengan kompetensi yang } \\
\text { dibutuhkan untuk mahasiswa S1 }\end{array}$ & 92,31 & 7,69 \\
\hline 5 & $\begin{array}{l}\text { Tingkat kesulitan naskah bacaan. } \\
\text { Pertanyaan: Apakah materi yang disampaikan mudah dipahami dengan tingkat } \\
\text { kesulitan yang sedang }\end{array}$ & 76,92 & 23,08 \\
\hline 6 & $\begin{array}{l}\text { Penggunaan Maple } \\
\text { Pertanyaan: Apakah dengan penggunaan Maple dapat membantu dalam memahami } \\
\text { materi? }\end{array}$ & 88,46 & 11,54 \\
\hline $7 a$ & $\begin{array}{l}\text { Integrasi-Interkoneksi dalam materi dan soal } \\
\text { Pertanyaan: Apakah ada integrasi-interkoneksi dalam uraian materi }\end{array}$ & 73,08 & 26,92 \\
\hline $7 b$ & $\begin{array}{l}\text { Integrasi-Interkoneksi dalam materi dan soal } \\
\text { Pertanyaan: Apakah ada integrasi-interkoneksi dalam permasalahan (soal dan latihan) }\end{array}$ & 69,23 & 30,77 \\
\hline
\end{tabular}

Secara garis besar penilaian dari mahasiswa tersebut, selanjutnya dibandingkan dengan penilaian dari pakar yang memiliki kompetensi dalam penguasaan materi mata kuliah Trigonometri. Ternyata setelah dilakukan analisis penilaian mahasiswa tersebut pada dasarnya berbanding lurus dengan pendapat para pakar dimaksud.

Gambaran utuh mengenai penilaian pakar terhadap seluruh bahan ajar Trigonometri dipaparkan pada Tabel 4. Data tingkat pencapaian dikonversi menurut skoring

Tabel 4. Hasil Analsis pakar terhadap aspek isi/materi pada mata kuliah Trigonometri

\begin{tabular}{|c|c|c|c|c|c|c|c|c|c|c|c|}
\hline \multirow{2}{*}{ No } & \multirow{2}{*}{ Materi } & \multicolumn{9}{|c|}{ Aspek } & \multirow{2}{*}{ Rata } \\
\hline & & $\mathbf{A}$ & B & $\mathrm{C}$ & D & $\mathbf{E}$ & $\mathbf{F}$ & G & $\mathbf{H}$ & I & \\
\hline 1 & BAB I & 7 & 5 & 5 & 7 & 7 & 5 & 7 & 5 & 5 & 5,89 \\
\hline 2 & BAB II & 5 & 5 & 3 & 7 & 5 & 3 & 7 & 7 & 5 & 5,22 \\
\hline 3 & BAB III & 5 & 5 & 5 & 5 & 3 & 3 & 7 & 7 & 5 & 5 \\
\hline 4 & BAB IV & 3 & 5 & 3 & 5 & 3 & 3 & 7 & 7 & 5 & 4,56 \\
\hline 5 & BAB V & 7 & 5 & 5 & 7 & 7 & 5 & 7 & 5 & 5 & 5,89 \\
\hline 6 & BAB VI & 5 & 5 & 3 & 7 & 5 & 3 & 7 & 7 & 5 & 5,22 \\
\hline & Rata & 5,33 & 5 & 4 & 6.33 & 5 & & 7 & 62 & 5 & 53 \\
\hline
\end{tabular}

\section{Keterangan:}

$\begin{array}{ll}\text { A } & \text { : Menjelaskan konsep dengan tuntas } \\ \text { B } & \text { : Metode konsisten dan berimbang } \\ \text { C } & \text { : Logis teratur dan koheren } \\ \text { D } & \text { : Sesuai jenjang S1 } \\ \text { E } & \text { : Membantu analisis berpikir }\end{array}$

Dari Tabel 4di atas dapat dijelaskan bahwa seluruh bab $(1-6)$, parameter tugas/tes sesuai materi memiliki skor 7 (sangat baik). Skor yang sama dicapai oleh parameter menjelaskan konsep dengan tuntas pada $\mathrm{BAB} \mathrm{I}$, parameter sesuai jenjang $\mathrm{S} 1$ pada $\mathrm{BAB}$ I dan BAB II, serta parameter membantu analisis berpikir pada $\mathrm{BAB}$ I.

Meskipun ada beberapa parameter yang memperoleh skor 3, namun berdasarkan analisis secara umum dapat disimpulkan bahwa rata-rata skor penilaian pakar terhadap seluruh bab untuk setiap parameter aspek fisik adalah cukup baik $(5,3)$. Dengan kata lain, parameter aspek materi untuk setiap bab tidak ada yang memiliki skor 1 . Artinya, secara umum materi seluruh bab dinilai

$\begin{array}{ll}\text { F } & \text { : Sudah mutahir } \\ \text { G } & : \text { Tugas/tes sesuai materi } \\ \text { H } & : \text { Penggunaan Maple } \\ \text { I } & \text { : Integrasi-interkoneksi }\end{array}$

dengan baik dan memuaskan, sebagaimana ditunjukan pada Tabel 4. hasil menunjukkan bahwa hampir semua bab masih membutuhkan keterkaitan integrasi-interkoneksi. Materi masih butuh dikaitkan dengan permasalahan tentang islam.

\subsection{Aspek Penyajian}

Untuk aspek penyajian, subkomponen yang menjadi acuan dalam penelitian ini meliputi aspek-aspek sebagai berikut.

a. Keterbacaan, dengan tolok ukurnya terdiri dari: (a) kalimat tidak bertele-tele dan tidak terlalu banyak anak kalimat; (b) penggunaan kalimat mudah dipahami (termasuk istilah asing); dan (c) kalimat yang disampaikan 
secara komunikatif sebagaimana layaknya bahan ajar .

b. Bahasa, dengan tolok ukur adalah: (a) menggunakan bahasa Indonesia yang baik dan benar dan (b) menggunakan aturan Ejaan Yang Disempurnakan (EYD) dan

c. Pengorganisasian isi, dengan tolok ukurnya meliputi: (a) pembagian bab cukup jelas; (b) sub pokok bahasan dalam bab dibedakan secara jelas dan konsisten; (c) ada kesinambungan/keterkaitan antara pokok bahasan dengan sub pokok bahasan; (d) ukuran huruf, panjang baris dan spasi antar baris cukup memadai bagi pembaca, materi ilustrasi memiliki judul yang jelas.

Untuk komponen keterbacaan bahan ajar Trigonometri, $88,46 \%$ mahasiswa memberi penilaian bahwa kalimat disampaikan mudah dipahami. Sementara sejumlah mahasiswa lainnya, 11,54\% menilai bahan ajar Trigonometri tidak mudah dipahami. Untuk parameter yang lainnya mempunyai persentasi dia atas 90\% bahkan sampai $100 \%$. Hal ini menunjukan bahwa bahan ajar ini dalam aspek penyajian sudah cukup baik. Selengkapnya dapat dilihat pada Tabel 5 .

Tabel 5. Persepsi Mahasiswa terhadap aspek penyajian bahan ajar Trigonometri

\begin{tabular}{|c|c|c|c|c|}
\hline \multirow{3}{*}{$\begin{array}{c}\text { No } \\
1 \mathrm{a}\end{array}$} & \multirow{2}{*}{\multicolumn{2}{|c|}{ Kriteria }} & \multicolumn{2}{|c|}{ Jabawan $(\%)$} \\
\hline & & & \multirow{2}{*}{$\begin{array}{c}\text { Ya } \\
96,15\end{array}$} & \multirow{2}{*}{$\begin{array}{r}\text { Tidak } \\
3,85\end{array}$} \\
\hline & keterbacaan & Kalimat tidak bertele dan tidak ada anak kalimat & & \\
\hline $1 b$ & & Penggunaan kalimat mudah dipahami & 92,31 & 7,69 \\
\hline $1 \mathrm{c}$ & & Kalimat disampaikan secara komunikatif & 88,46 & 11,54 \\
\hline $2 \mathrm{a}$ & Bahasa & Menggunakan bahasa baik dan benar & 92,31 & 7,69 \\
\hline $2 b$ & & Menggunakan bahasa sesuai EYD & 92,31 & 7,69 \\
\hline $3 \mathrm{a}$ & pengorganisasian & Pembagian bab cukup jelas & 100 & 0 \\
\hline $3 b$ & & Subbab dibedakan dengan jelas & 100 & 0 \\
\hline $3 \mathrm{c}$ & & Ada kaitan antara bab dan subbab & 96,15 & 3,85 \\
\hline $3 d$ & & Ukuran huruf, panjang baris dan spasi sesuai & 100 & 0 \\
\hline
\end{tabular}

Berdasarkan Tabel 5 dapat ditegaskan bahwa, untuk bahan ajar Trigonometri parameter pada bahan ajar berada pada tingkat pencapaian sangat baik $(>80 \%)$. Kenyataan ini memberikan gambaran bahwa aspek penyajian bahan ajar sudah memuaskan, sesuai dengan persepsi mahasiswa. Selain itu, beberapa mahasiswa diminta untuk mereviu bahan ajar trigonometri diperoleh hasil pada Tabel 6 .

Tabel 6. Persepsi Mahasiswa Terhadap Aspek Isi/Materi Bahab Ajar

\begin{tabular}{|l|l|l|l|}
\hline No & Kriteria & Komentar & Kesimpulan \\
\hline 1 & Keakuratan materi & $\begin{array}{l}\text { Materi yang ingin disampaikan sesuai dengan kebutuhan } \\
\text { mahasiswa }\end{array}$ & Akurat \\
\hline 2 & $\begin{array}{l}\text { Alur dan kelengkapan } \\
\text { materi }\end{array}$ & $\begin{array}{l}\text { Materi yang disampaikan sangat rinci sehingga mahasiswa } \\
\text { dapat memahami materi dengan cepat dan jelas }\end{array}$ & Lengkap \\
\hline $3 a$ & Kemuktahiran dan & Tepat sasaran dan efektif dan efisien & $\begin{array}{l}\text { Materi } \\
\text { muktahir }\end{array}$ \\
\hline $3 b$ & Pengayaan materi & $\begin{array}{l}\text { Hubungan pemateri dan mahasiswa sangat baik ketika } \\
\text { pengayaan sehingga mahasiswa merasa nyaman }\end{array}$ & Ada \\
\hline 4 & $\begin{array}{l}\text { Ketepatan terhadap } \\
\text { sasaran pembaca }\end{array}$ & Sangat jelas dan rinci sehingga dapat dipahami dengan cepat & $\begin{array}{l}\text { Tepat untuk } \\
\text { pembaca }\end{array}$ \\
\hline 5 & $\begin{array}{l}\text { Tingkat kesulitan } \\
\text { naskah bacaan }\end{array}$ & $\begin{array}{l}\text { Bacaan yang digunakan sesuai dengan standar bacaan yang } \\
\text { fleksibel dan tidak ambigu }\end{array}$ & $\begin{array}{l}\text { Tidak cukup } \\
\text { tinggi }\end{array}$ \\
\hline 6 & $\begin{array}{l}\text { Penggunaan Maple } \\
\text { dalam penyampaian } \\
\text { materi }\end{array}$ & $\begin{array}{l}\text { Materi menggunakan maple 50\% dari teori karena ada meteri } \\
\text { yang membutuhkan komputasi }\end{array}$ & $\begin{array}{l}\text { Sangat } \\
\text { mendukung }\end{array}$ \\
\hline
\end{tabular}

Berdasarkan hasil reviu mahasiswa di atas terlihat bahwa baik aspek isi/materi dan penyajian bahan ajar sudah sesuai dengan apa diharapkan. Artinya bahan ajar sudah layak dijadikan bahan 
ajar untuk mahasiswa Jurusan Pendidikan Matematika Fakultas Ilmu Tarbiyah dan keguruan IAIN Mataram.

\subsection{Hasil Prestasi Belajar}

Secara umum mahasiswa yang mengikuti perkuliahan dapat dikatakan lancar dan sesuai dengan rancangan perkuliahan yang telah direncanakan. Perkuliahan diadakan 6 kali pertemuan. Berdasarkan hasil tes/kuis yang diberikan kepada mahasiswa sebanyak 26 orang mahasiswa dari 26 orang diperoleh data mahasiswa mendapatkan nilai tertinggi 95,83 (grade A) dan nilai terendah 54,17 (grade D). Mahasiswa yang mendapatkan nilai dengan grade A sebesar 11,54 \%, nilai dengan grade B sebesar $61,54 \%$, dan nilai dengan grade $\mathrm{C}$ sebesar $19,23 \%$. Sedangkan mahasiswa yang mendapatkan nilai dengan grade D sebesar 3,85 \% dan nilai dengan grade $\mathrm{E}$ sebesar $3,85 \%$. Hasil selengkapnya dapat dilihat pada Tabel 7 .

Tabel 7. Data hasil prestasi belajar mahasiswa semester V kelas D Jurusan Pendidikan Matematika Tahun Akademik 2013/2014

\begin{tabular}{|c|c|c|c|c|c|c|c|c|c|c|}
\hline \multirow{2}{*}{ NO } & \multirow{2}{*}{ NIM } & \multirow{2}{*}{ NAMA } & \multicolumn{6}{|c|}{ Soal } & \multirow{2}{*}{ Total } & \multirow{2}{*}{ Huruf } \\
\hline & & & 1 & 2 & 3 & 4 & 5 & 6 & & \\
\hline 1 & 15.1.13.4.001 & ABDURRAHMAN & 5 & 20 & 10 & 20 & 20 & 0 & 62,5 & $\mathrm{C}$ \\
\hline 2 & 15.1.13.4.002 & HUSNUL AINI & 5 & 20 & 20 & 20 & 20 & 0 & 70,83 & B \\
\hline 3 & 15.1.13.4.003 & YUNITA SUSILAWATI & 5 & 10 & 20 & 20 & 10 & 20 & 70,83 & B \\
\hline 4 & 15.1.13.4.006 & MAR'ATUL AINI & 0 & 20 & 20 & 0 & 0 & 0 & 33,33 & $\mathrm{E}$ \\
\hline 5 & 15.1.13.4.007 & SOLLIALA & 5 & 20 & 5 & 20 & 20 & 15 & 70,83 & B \\
\hline 6 & 15.1.13.4.008 & ARDI SURYADI & 0 & 10 & 20 & 15 & 10 & 10 & 54,17 & $\mathrm{D}$ \\
\hline 7 & 15.1.13.4.009 & ROSITA SARI & 15 & 20 & 20 & 20 & 20 & 20 & 95,83 & A \\
\hline 8 & 15.1.13.4.010 & ZULFAN RHAMDANY & 5 & 20 & 10 & 20 & 20 & 10 & 70,83 & B \\
\hline 9 & 15.1.13.4.011 & ALFIN NURAENI & 15 & 20 & 5 & 20 & 20 & 10 & 75 & $\mathrm{~B}$ \\
\hline 10 & 15.1 .13 .4 .012 & HASANAH & 5 & 20 & 15 & 20 & 20 & 5 & 70,83 & $\mathrm{~B}$ \\
\hline 11 & 15.1.13.4.013 & SITI MAEMUNAH & 10 & 20 & 20 & 17 & 10 & 13 & 75 & B \\
\hline 12 & 15.1.13.4.015 & ZOHRATUN NAZIRA & 5 & 20 & 5 & 20 & 20 & 15 & 70,83 & $\mathrm{~B}$ \\
\hline 13 & 15.1.13.4.016 & DIAN KURNIAWATI & 5 & 20 & 15 & 10 & 10 & 15 & 62,5 & $\mathrm{C}$ \\
\hline 14 & 15.1.13.4.017 & SRI WAHYUNI & 5 & 20 & 20 & 20 & 10 & 15 & 75 & $\mathrm{~B}$ \\
\hline 15 & 15.1.13.4.018 & WARDATUL ISLAMIYAH & 10 & 20 & 20 & 8 & 20 & 5 & 69,17 & $\mathrm{~B}$ \\
\hline 16 & 15.1.13.4.019 & SUSANTI H MANSARI & 10 & 15 & 20 & 20 & 20 & 15 & 83,33 & A \\
\hline 17 & 15.1.13.4.020 & SABAHUL KHOIRI & 20 & 20 & 15 & 10 & 15 & 10 & 75 & $\mathrm{~B}$ \\
\hline 18 & 15.1.13.4.021 & SUKMA MAWADDAH & 15 & 20 & 5 & 20 & 5 & 10 & 62,5 & $\mathrm{C}$ \\
\hline 19 & 15.1.13.4.022 & MURNIAWATI & 5 & 15 & 15 & 20 & 20 & 0 & 62,5 & $\mathrm{C}$ \\
\hline 20 & 15.1.13.4.023 & THURMUZI THAHIR & 15 & 15 & 15 & 5 & 20 & 15 & 70,83 & $\mathrm{~B}$ \\
\hline 21 & 15.1.13.4.024 & $\begin{array}{l}\text { NINGSIH WAHYU NINGS } \\
\mathrm{IH}\end{array}$ & 10 & 15 & 20 & 20 & 20 & 10 & 79,17 & B \\
\hline 22 & 15.1.13.4.025 & OLIVIA ANGGRAINI & 15 & 15 & 15 & 20 & 10 & 10 & 70,83 & $\mathrm{~B}$ \\
\hline 23 & 15.1 .13 .4 .026 & SUPRIANTO & 5 & 20 & 20 & 5 & 20 & 15 & 70,83 & $\mathrm{~B}$ \\
\hline 24 & 15.1.13.4.027 & YOVIETA LESTARI & 15 & 10 & 20 & 20 & 20 & 15 & 83,33 & A \\
\hline 25 & 15.1.13.4.028 & IRWAN JAYADI & 5 & 15 & 20 & 10 & 15 & 10 & 62,5 & $\mathrm{C}$ \\
\hline 26 & 15.1.13.4.029 & SITI MARIA HULFA & 15 & 20 & 20 & 15 & 10 & 10 & 75 & B \\
\hline \multicolumn{3}{|c|}{ Jumlah mahasiswa yang ikut ujian } & \multicolumn{8}{|c|}{26 orang dari 26 orang } \\
\hline \multicolumn{3}{|c|}{ Jumlah mahasiswa yang tidak ujian } & \multicolumn{8}{|c|}{0 orang } \\
\hline \multicolumn{3}{|c|}{ Nilai tertinggi } & \multicolumn{8}{|c|}{95,83} \\
\hline \multicolumn{3}{|c|}{ Nilai terendah } & \multicolumn{8}{|c|}{33,33} \\
\hline
\end{tabular}




\begin{tabular}{|c|c|}
\hline Rata-rata & 70,13 (grade B) \\
\hline Jumlah mahasiswa yang lulus & 19 orang \\
\hline Jumlah mahasiswa yang tidak lulus & 7 orang \\
\hline Porsentase kelulusan & $72 \%$ \\
\hline Porsentase yang tidak lulus & $28 \%$ \\
\hline
\end{tabular}

Berdasarkan tabel di atas, hasil yang diperoleh ternyata jumlah mahasiswa yang lulus setelah perkuliahan pada mata kuliah Trigonometri mendapatkan porsentase $72 \%$. Hasil yang diperoleh lebih tinggi dari parameter yang ditentukan sebesar $70 \%$. Ini menunjukkan bahwa bahan ajar mata kuliah Trigonometri sudah layak dipakai.

\section{Kesimpulan}

Bahan ajar yang dikembangkan sudah layak digunakan. Kondisi komponen bahan ajar, antara lain Peta kompetensi dan Garis Besar Program Pengajaran sudah konsisten. Uraian pokok bahasan dan sub pokok bahasab perlu ditambah konsep yang lebih lengkap. Materi bahan ajar mata kuliah Trigonometri sudah layak digunakan sebagai sumber pengajaran.

Berdasarkan persepsi pakar dan mahasiswa etrkait dengan aspek isi/materi dan aspek penyajian dinilai baik dan memuaskan. Penggunaan Maple masih pada tingkat 65\% - 80\% dalam materi bahan ajar trigonometri. Hal ini disebabkan oleh ada beberapa materi trigonomteri yang tidak bisa digunakan dengan menggunakan Maple seperti dalam membuktikan rumus identitas dari trigonometri. Maple digunakan dalam menyelesaiakan masalah. Ketuntasan Belajar mahasiswa pada mata kuliah Trigonometri sebesar $72 \%$ lebih besar dari ketuntasan yang ditentukan sebesar $70 \%$.

Integrasi dan interkoneksi yang terkait dalam materi trigonometri dapat lihat dari awal munculnya ilmu pengetahuan. Hal ini karena banyaknya cendekiawan muslim yang bergelut di dalam berkembangnya ilmu pengetahuan khususnya trigonometri. Aplikasinya masih bisa digunakan seperti dalam penentuan hilal di awal bulan ramadhan dan bulan syawal..

\section{Daftar Pustaka}

Andy Ruhito, M. 2009. Pelatihan Maple. JPMIPA USD Yogyakarta.
Fadillah, I dan Heryadi, H. 2010. Kajian Pengembangan Materi dan Kemuktahiran Bahan Ajar Matakuliah Kewirausahaan.

Gabriel, dkk. 2006. Pengantar Metode Penelitian. Jakarta: UI-Press.

Limbong, A, dkk. 2006. Evaluasi Bahan Ajar Jarak Jauh (Langkah Praktis). PAU-PPI Universitas Terbuka Jakarta.

Slameto. 2003. Belajar dan Faktor-Faktor yang Mempengaruhinya. Jakarta: Rineka Cipta.

Sugiyono. 2012. Metode Penilaian Pendidikan (Pendekatan Kuantitatif, Kualitatif, dan R/D). Bandung:Alfabeta.

Suharsimi Arikunto. 2010. Prosedur Penelitian Suatu Pendekatan Praktik. Jakarta: Rineka Cipta.

Undang-undang Republik Indonesia Nomor 2 tentang Sistem Pendidikan Nasional. (1990). Jakarta: PT. Armas Duta Jaya 
